\title{
Provision of astigmatid mites as supplementary food increases the density of the predatory mite Amblyseius swirskii in greenhouse crops, but does not support the omnivorous pest, western flower thrips
}

\author{
Fatemeh Pirayeshfar $(\mathbb{D} \cdot$ Seyed Ali Safavi $\mathbb{D}$ - Hamid Reza Sarraf Moayeri $\mathbb{D}$ - \\ Gerben J. Messelink
}

Received: 13 July 2020 / Accepted: 3 May 2021 / Published online: 20 May 2021

(C) The Author(s) 2021

\begin{abstract}
Astigmatid mites can be used as prey for mass rearing of phytoseiid predators, but also as a supplemental food source to support predator populations in crops. Here we evaluated the potential of six species of astigmatid mites (living or frozen) as alternative food for the predatory mite Amblyseius swirskii Athias-Henriot in greenhouse crops. All prey mites tested were suitable for predator oviposition. In general, oviposition was greater when prey mites were reared on dog food with yeast than when they were reared on wheat bran with yeast. Amongst prey items provided as frozen diet, larvae of Thyreophagus entomophagus (Laboulbene), Acarus siro L. and Lepidoglyphus destructor (Schrank) that had been reared on dog food with yeast, resulted in the highest oviposition rates of A. swirskii. T. entomophagus
\end{abstract}

Handling Editor: Eric Riddick.

F. Pirayeshfar $(\bowtie) \cdot$ S. A. Safavi

Department of Plant Protection, Faculty of Agriculture,

Urmia University, P.O. Box 57135-165, Urmia,

West Azerbaijan, Iran

e-mail: f.pirayeshfar@urmia.ac.ir

F. Pirayeshfar · G. J. Messelink

Business Unit Greenhouse Horticulture, Wageningen

University \& Research, P.O. Box 20, 2265 ZG Bleiswijk,

The Netherlands

H. R. S. Moayeri

Department of Plant Protection, Faculty of Agriculture,

University of Zanjan, P.O. Box 45195-313, Zanjan, Iran larvae as frozen diet resulted in the shortest preimaginal developmental time of $A$. swirskii. On chrysanthemum plants, we found that the greatest increase in predator density occurred when living mites of $T$. entomophagous were used as a food source. This increase was greater than when predators were fed cattail pollen, a commonly used supplemental food. Effects on predators of providing living $A$. siro and $L$. destructor, or frozen larvae of T. entomophagous as food, were comparable with provision of pollen. Use of supplemental food in crops can be a risk if it is also consumed by omnivorous pests such as western flower thrips, Frankliniella occidentalis Pergande. However, we showed that both frozen and living mites of $T$. entomophagous were unsuitable for thrips oviposition. Hence, we believe that provision of prey mite species increases A. swirskii density, supporting biological control of thrips and other pests in greenhouse crops.

Keywords Factitious diets - Storage mites · Thyreophagus entomophagus $\cdot$ Pollen $\cdot$ Frankliniella occidentalis

\section{Introduction}

Predatory mites in the family Phytoseiidae are one of the most important natural enemies used in augmentative biological pest control (Gerson and Weintraub 
2007; McMurtry et al. 2013; van Lenteren et al. 2018). A major breakthrough in biological control was the discovery that astigmatid mites could be used as prey/ food for rearing of phytoseiid predatory mites, enabling mass production of predators at low cost (Schliesske 1981; Ramakers and van Lieburg 1982). Many species of predatory mites are now mass produced on astigmatid mites, although the production systems reported in the literature remain limited (Bolckmans and van Houten 2006; Simoni et al. 2006; Midthassel et al. 2013). Generalist phytoseiid predatory mites, classified as Type III, feed on multiple prey species and also pollen (McMurtry et al. 2013), and are the predatory mites best suited to mass rearing on astigmatids (Barbosa and de Moraes 2015). Amongst them, Amblyseius swirskii (AthiasHenriot) is widely used because of its efficacy against a wide range of important pests, including thrips, whiteflies and plant-feeding mites (Nomikou et al. 2002; Messelink et al. 2006, 2008, 2010; Arthurs et al. 2009; van Maanen et al. 2010). Currently, A. swirskii is used in more than 50 countries for biological pest control in vegetable and ornamental crops, making it one of the most successful biological control agents worldwide (Buitenhuis et al. 2015; Calvo et al. 2015; Janssen and Sabelis 2015). However, releases of predatory mites do not always result in good establishment, mainly due to a lack of suitable food sources in the crops. This is particularly the case in ornamental crops where pest tolerance is low.

One solution to overcoming food scarcity is the provision of alternative food sources (Messelink et al. 2014; Janssen and Sabelis 2015). Pollen has been widely used as an alternative food source and can successfully support predatory mite populations and increase pest control (Nomikou et al. 2010). However, pollen is also an excellent food source for pests such as western flower thrips, Frankliniella occidentalis Pergande leading to temporarily high thrips densities under some circumstances (van Rijn et al. 2002; Leman and Messelink 2015; Vangansbeke et al. 2016). Besides pollen, there are many other factitious (nonnatural) hosts that offer opportunities as alternative food sources for predatory mite populations in crops. These include Artemia sp. cysts, Ephestia kuehniella Zeller eggs and different species of astigmatid mites (Hoogerbrugge et al. 2008; Messelink et al. 2009).

Astigmatid mites as an alternative food for predatory mites has particular potential because of the low cost of mass production and the recent finding that, for at least one species, they do not support reproduction of thrips (Pirayeshfar et al. 2020). The use of astigmatid mites in greenhouse crops is increasingly being explored in practice (Messelink et al. 2014). Many species of astigmatid mites have been evaluated for use in the mass production of predatory mites, such as Acarus farris (Oudemans) (Ramakers and van Lieburg 1982), Carpoglyphus lactis (L.) (Bolckmans and van Houten 2006; Nguyen et al. 2013), Suidasia medanenesis (Oudemans) (Midthassel et al. 2013), Lepidoglyphus destructor (Schrank) (Simoni et al. 2006) and Tyrophagus putrescentiae (Schrank) (Riahi et al. 2017). However, little is known about the performance of different astigmatid mite species in crops and their potential contribution as alternative food for predatory mite populations.

Prey mites that are suitable for mass rearing are not necessarily suitable for application in the crop, because of the totally different environmental conditions in crops compared with mass rearing systems. Considerations for evaluation include whether astigmatid mites cause any potential feeding damage to young and soft plant tissues (Hiroshi 1991), and whether high numbers of astigmatid mites pose a risk to human health because of their association with allergies (Johansson et al. 1994; Hubert et al. 2018). One method to minimize the risk of allergies is to freeze-kill the mites before application. This was recently evaluated for the astigmatid mite $T$. putrescentiae by Pirayeshfar et al. (2020) who found that frozen stages could support development and oviposition of A. swirskii in the laboratory, but not on plants in a greenhouse. Based on this study, we hypothesise that it might be worthwhile testing the same method with other astigmatid mite species. Interestingly, the study of Pirayeshfar et al. (2020) showed that both the prey life stage and the food on which it had been reared affected predatory mite performance. Highest oviposition rates in predatory mites were achieved when they were fed on diets based on frozen prey larvae.

In the current study, the potential of living and frozen stages (eggs and larvae) of six species of astigmatid mites to support oviposition and population increase of A. swirskii were compared with two sources of pollen. In addition, we evaluated the suitability of astigmatid mite stages as a food source for F. occidentalis. The purpose of this study was to select the most suitable astigmatid mite species based 
on nutritional value and how they were presented (living or frozen) as an alternative food source for supporting populations of the predatory mite $A$. swirskii in greenhouse crops.

\section{Materials and methods}

Mite and thrips cultures

The stock colony of A. swirskii was initially obtained from Koppert Biological Systems (Berkel en Rodenrijs, The Netherlands) and subsequently reared on pollen provided to leaves of sweet pepper, Capsicum annuиm L. cv. Spider (Enza Zaden, Enkhuizen, The Netherlands). The leaves were placed upside down on water-saturated cotton wool in plastic containers $(18 \times 12 \times 5 \mathrm{~cm})$. Wet tissue papers were attached to the edge of the leaves to provide moisture and prevent predatory mites from escaping (van Rijn and Tanigoshi 1999). The predators were fed every two days with cattail pollen (Typha angustifolia L.) as a standard diet for A. swirskii rearing (Nguyen et al. 2013). All laboratory oviposition experiments were done with 4-5 day-old $A$. swirskii females collected from the laboratory culture, but for the greenhouse trial, the predatory mites came directly from the commercial product obtained from Koppert (which had been reared on $C$. lactis with bran).

Six species of astigmatid mites from four families were evaluated: (1) Acaridae: Thyreophagus entomophagus (Laboulbene), Aleuroglyphus ovatus (Tropeau) and Acarus siro L.; (2) Suidasiidae: Suidasia nesbitti Hughes and (3) Glycyphagidae: L. destructor and (4) Carpoglyphidae: C. lactis. The astigmatid mites came from various sources and had been maintained for several years by BU Greenhouse Horticulture of Wageningen University and Research in the Netherlands. For each species, two colonies were established and each maintained on a different food source in order to produce prey mites with different nutritional values.

All astigmatid mite species were reared on either wheat bran (Havens, Maashees, The Netherlands) or crushed dry dog food (Royal Canin, Veghel, The Netherlands). Wheat bran represents a low fat, low protein and high carbohydrate diet while crushed dog food represents a high fat, high protein and low carbohydrate diet (Erban et al. 2015). Both diets were supplemented with the same quantity of instant dry bakers' yeast (Mauripan, Hampton, United Kingdom) (50/50 by weight), which is known to be a suitable food source for astigmatid mites (Huang et al. 2013). While yeast also contains proteins, the difference in protein level between the two diets remained constant after addition of the yeast. Although yeast was present in two diets, based on their main constituent, both of diets are referred to as 'dog food' and 'bran' from here.

Each astigmatid mite species was reared for several generations in a plastic box $(10 \mathrm{~cm}$ in diameter, $6 \mathrm{~cm}$ in high) which was embedded in a larger glass container (14 $\mathrm{cm}$ diameter, $8 \mathrm{~cm}$ high) covered with a lid and filled with a $1 \mathrm{~cm}$ layer of a saturated $\mathrm{KNO}_{3}$ solution to prevent mite escape and provide a high and constant humidity level of 93\% (Winston and Bates 1960). Colonies of A. swirskii were maintained in a different climate chamber to the astigmatid prey mites but both were under long day illumination (L:D 16:8) at $25^{\circ} \mathrm{C}$ and $70 \% \mathrm{RH}$.

Western flower thrips, $F$. occidentalis were maintained for many generations on flowering chrysanthemum plants (Dendranthema grandiflora Tzvelev cv. Tapas Time), in a separate greenhouse compartment, and provided with artificial light and heating during winter. The plants were kept in cages to avoid contamination by other herbivores and replaced frequently.

\section{Factitious prey diets}

For each astigmatid mite species, six different factitious diets were prepared (36 treatments in total) as follows: (1) by life stage (mixed living, frozen eggs or frozen larvae) and (2) by prey mite diet (dog food or bran) (Table 1). The eggs of all astigmatid mite species were individually separated from other life stages by sieving colonies through a $100 \mu \mathrm{m}$ mesh screen and stored at $-20{ }^{\circ} \mathrm{C}$ for at least $4 \mathrm{~h}$ before use in the experiments. A proportion of the sieved eggs (instead of being stored at $-20^{\circ} \mathrm{C}$ ) were incubated for $48-72 \mathrm{~h}$ under the conditions described previously, until more than $80 \%$ developed into larvae, which was confirmed under a dissecting microscope. Newly hatched larvae were also stored at $-20^{\circ} \mathrm{C}$ for at least $24 \mathrm{~h}$ before use in experiments (Pirayeshfar et al. 2020). Before experimental use, frozen diets were thawed at room temperature $\left(20 \pm 2{ }^{\circ} \mathrm{C}\right)$ for ca. $30 \mathrm{~min}$. Cattail pollen (Nutrimite TM) was supplied by Biobest N.V., 
Table 1 Different diets based on six species of astigmatid prey mites, Thyreophagus entomophagus, Aleuroglyphus ovatus, Acarus siro, Suidasia nesbitti, Lepidoglyphus destructor and Carpoglyphus lactis

\begin{tabular}{ll}
\hline Mite composition & Food substrate \\
\hline Mixed life stages & Wheat bran + dry yeast \\
Mixed life stages & Dog food + dry yeast \\
Frozen eggs & Wheat bran + dry yeast \\
Frozen larvae & Wheat bran + dry yeast \\
Frozen eggs & Dog food + dry yeast \\
Frozen larvae & Dog food + dry yeast \\
\hline
\end{tabular}

(Westerlo, Belgium) and used as a reference for all laboratory and greenhouse trials. Olive (Olea europaea L.) pollen was used as a second reference, because it is easily collected in large quantities and is known to support reproduction of $A$. swirskii (Kumar et al. 2014; Nemati et al. 2019). The olive pollen in our study was provided by the Olive Research Station of Tarom, Zanjan, Iran. For long-term storage, both pollens were stored at $-20{ }^{\circ} \mathrm{C}$.

\section{Oviposition of A. swirskii}

Oviposition rates of the predatory mite, A. swirskii feeding on the 36 factitious diets and two pollen sources (cattail or olive) were measured over three consecutive days. Peak oviposition rates of phytoseiid mites (which occur during the first days after the preoviposition period) are known to be strongly correlated with population growth rates (Janssen and Sabelis 1992) and so we limited the time period for measurement of oviposition to only three days. Data from the first day were omitted to limit effects of the pre-experimental diet (Sabelis 1990). Gravid female A. swirskii (4-5 days since adult emergence) were placed individually on $2.5 \mathrm{~cm}$ sweet pepper $(C$. апnиит) leaf discs in $5 \mathrm{~cm}$ diameter Petri dishes. Each leaf disc was floating on water with the abaxial side uppermost and fixed with a modified paper clip stand that had been glued to the base of the Petri dish before filling with water (Pirayeshfar et al. 2020). Dishes were closed with a fine mesh lid to allow ventilation. Each disc had a leaf axil as a domatium for A. swirskii oviposition (Faraji et al. 2002). There were 20 replicate experimental units for each food treatment. According to food treatment, the diet was introduced into each unit in the following quantities:
$0.01 \mathrm{~g}$ of pollen, $0.01 \mathrm{~g}$ frozen diet, or 40-50 mixed living life stages (predominantly eggs and larvae). Predatory mite eggs were counted and removed daily to prevent cannibalism. Based on this oviposition experiment, we selected the astigmatid mite species with greatest potential for subsequent trials. The experiment was done in a climate chamber under long day illumination (L:D 16:8) at $25^{\circ} \mathrm{C}$ and $70 \% \mathrm{RH}$.

Survival and juvenile development

Based on the observed oviposition rates of A. swirskii fed on different food diets (pollens and frozen diets), we selected five food treatments to evaluate immature developmental time and survival of $A$. swirskii. To obtain synchronized $A$. swirskii eggs, ca. 100 mated females were transferred from the cultures to a new rearing arena (larger than the oviposition experimental unit) with cattail pollen. After $24 \mathrm{~h}$, their eggs were transferred individually to the experimental units, as described for the oviposition experiment. Diets were added to each unit $(0.01 \mathrm{~g})$ after larval emergence. Old diet was removed every $48 \mathrm{~h}$ and replaced with fresh diet. The duration of each life stage was determined based on the presence of exuvia as evidence of moulting. Survival and development of individuals were recorded daily until mites reached adulthood. There were 20 replicates for each diet. The experiment was done in a climate chamber under long day illumination (L:D 16:8) at $25{ }^{\circ} \mathrm{C}$ and $70 \% \mathrm{RH}$.

\section{Greenhouse trial}

Based on the two laboratory experiments, eight food treatments, including the two reference pollens (cattail and olive) and six factitious prey diets (frozen and living stages of three species of the prey mites) were selected to assess their influence on establishment and population growth of $A$. swirskii on chrysanthemum plants in a greenhouse trial. The selected prey mites were A. siro, L. destructor and T. entomophagus, which were all reared on dog food. The trial was done in two adjacent greenhouse compartments at Wageningen University \& Research, BU Greenhouse Horticulture in Bleiswijk, The Netherlands. Each compartment had an area of $24 \mathrm{~m}^{2}$ and three tables, each of $7 \mathrm{~m}^{2}$. The trial was set up using a randomized complete block design with five replicates using each table as a block with eight treatments (two tables in 
one compartment and three in the other). Young chrysanthemum plants (Dendranthema $\times$ grandiflorum cv. Baltica) were supplied by Deliflor (Maasdijk, The Netherlands) and were planted in $12 \mathrm{~cm}$ diameter pots filled with peat. Each experimental unit (serving as a replicate) contained nine pots, each with one plant bearing 6-8 leaves at the start of the trial. All plants were placed on water-saturated irrigation mats to prevent predatory mite migration and minimise contamination amongst treatments. Plants were irrigated with a standard nutrient solution using an ebb-andflow irrigation system for $10 \mathrm{~min}$ per day. Predatory mites were introduced by adding three sweet pepper leaf discs (4 cm diameter) each containing 15 gravid female A. swirskii on top of the nine plants in each treatment (45 in total, thus approximately five per plant). The predatory mites were collected using a fine brush directly from the commercial product and placed on the pepper leaves for transfer. Food treatments $\left(0.06 \mathrm{~g}_{\text {plant }}{ }^{-1}\right)$ were added shortly after the predator releases by dusting with a fine brush to achieve an even distribution. For treatments containing living stages of the prey mites, approximately 500 different mobile stages were released per plant (counted based on weight). Population density of $A$. swirskii was monitored weekly for five consecutive weeks, before the flowering stage of chrysanthemum began, starting one week after releasing the predatory mites. All stages of $A$. swirskii on 18 randomly picked leaves per replicate (two leaves per plant) were counted. Temperature and RH during the experiment were recorded every $5 \mathrm{~min}$ with a climate recorder (Hoogendoorn Growth Management, Vlaardingen, the Netherlands). The climatic conditions in the two adjacent compartments were similar: the average temperature was $19.3{ }^{\circ} \mathrm{C}$ (range $12.2-29.6{ }^{\circ} \mathrm{C}$ ) and $19.3^{\circ} \mathrm{C}$ (range $12.8-28.4{ }^{\circ} \mathrm{C}$ ) and the average $\mathrm{RH} 72 \%$ (range $46-88 \%$ ) and $72 \%$ (range $47-87 \%$ ).

Oviposition of $F$. occidentalis on astigmatid mite diets

Based on the results from the laboratory experiments and greenhouse trial, we selected the most promising astigmatid food treatments and evaluated their suitability as food sources for western flower thrips. The mite diets were compared with the two reference pollen diets. Food suitability was assessed by measuring the oviposition rates of $F$. occidentalis females when fed on these diets for four consecutive days, using a double parafilm method modified from that of Teulon and Penman (1991). Each experimental unit was made of a perspex cylinder ( $30 \mathrm{~mm}$ height and 25 $\mathrm{mm}$ diameter) that was closed with a mesh (size 80 $\mu \mathrm{m})$ at one end to allow ventilation and by two layers of stretched parafilm at the other end. Four food diets were evaluated: (1) cattail pollen $\left(0.03 \mathrm{~g} \mathrm{unit}^{-1}\right),(2)$ olive pollen $\left(0.03 \mathrm{~g} \mathrm{unit}^{-1}\right)$, (3) mixed living stages of T. entomophagus (about 100 mites, predominantly eggs and larvae per unit) and (4) frozen larvae of $T$. entomophagus $\left(0.03 \mathrm{~g} \mathrm{unit}^{-1}\right)$. After adding the diets, three $F$. occidentalis females of unknown age were introduced into each unit and then immediately covered with a first layer of parafilm to retain the thrips inside the cylinder. After placing small droplets of water on the surface of the first layer of parafilm, the second layer was also covered. The number of eggs laid in the double parafilm membrane was counted daily. Each food treatment had 17 replicates (units).

\section{Statistical analysis}

To analyse the effects of diet on oviposition rates of $A$. swirskii (mean of days 2 and 3 ) and oviposition rates of thrips (mean of days 2, 3 and 4), we fitted generalised linear models (GLM) with a Poisson error distribution and log link function. Dispersion parameters were estimated to correct for overdispersion. Diet effects on juvenile developmental time of A. swirskii were also analysed with GLM, but with a normal distribution and identity link function for protonymphs and deutonymphs and a gamma distribution with a reciprocal link function for the total juvenile developmental time. Pairwise t-test were performed assuming that parameter estimates are approximately normally distributed (McCullagh and Nelder, 1983). We used Fisher's exact test to analyse differences in juvenile mortality among treatments. Population dynamics of predatory mites over time (total numbers of all stages) in the greenhouse trial were analysed using a generalized linear mixed model (GLMM) with a Poisson error distribution and log link function and an estimated dispersion parameter. We evaluated the statistical significance using an approximate F-test (Kenward and Roger 1997). Predatory mite density was the response variate, and food treatment was the fixed factor. Both block and time were included as random factors (time nested in block). Differences 
amongst treatments were compared using pairwise $t$ tests. All statistical analyses were done using the statistical package GenStat (Release 19.1).

\section{Results}

\section{Oviposition of $A$. swirskii}

There was a significant effect of diet treatment on oviposition rates of A. swirskii $\left(\mathrm{F}_{37,759}=9.68\right.$, $\mathrm{p}<0.001)$. In general, oviposition rates of $A$. swirskii increased when prey mites had been fed with dog food compared with bran, but this increase was only significant for A. siro, A. ovatus and L. destructor (Fig. 1). Oviposition rates of $A$. swirskii on prey mites were highest in the A. siro treatment (when fed with $\operatorname{dog}$ food), reaching similar rates as that achieved by $A$. swirskii in the pollen treatment. Oviposition rates of $A$. swirskii in all other diets of living prey mite species (when fed dog food) were similar to each other (Fig. 1). In general, highest A. swirskii oviposition rates were achieved in frozen prey mite treatments (when fed with dog food) (Fig. 1). Highest A. swirskii oviposition rates were achieved on the prey mite $A$. siro, followed by $L$. destructor, T. entomophagus, $S$. nesbitti and $C$. lactis. A lower oviposition rate was observed in the A. ovatus prey mite treatment (Fig. 1). The mean two-day oviposition rate of $A$. swirskii on olive pollen (not shown in Fig. 1) was not significantly different from cattail pollen $(3.45 \pm 0.34$ versus $4.25 \pm 0.32$, respectively).

Survival and juvenile development

The predatory mite A. swirskii survived and successfully developed on all diets evaluated. Significant differences amongst treatments were observed for the duration of the protonymph stage $\left(\mathrm{F}_{4,99}=19.02\right.$, $\mathrm{p}<0.001)$, deutonymph stage $\left(\mathrm{F}_{4,99}=5.60\right.$, $\mathrm{p}<0.001)$ and the total juvenile development time from larva to adult $\left(\mathrm{F}_{4,99}=18.98, \quad \mathrm{p}<0.001\right)$ (Table 2). Developmental time was shortest in the olive pollen treatment, but mortality was also higher on olive pollen than the other diets $(\mathrm{p}=0.045$; Fisher's exact test, Table 2). When fed the frozen prey diets, developmental time of A. swirskii, from larva to adult, was significantly longer for $L$. destructor than for $T$. entomophagous and $A$. siro.
Consumption of all frozen diets resulted in a longer developmental time for $A$. swirskii than consumption of the pollen treatments (Table 2).

\section{Greenhouse trial}

There was a significant effect of treatment on the population densities of predatory mites on chrysanthemum plants $\left(\mathrm{F}_{7}, 168=46.17, \mathrm{p}<0.001\right.$, Fig. 2$)$. Supplementation with mixed living stages of $T$. entomophagus (Te) resulted in the highest overall densities of A. swirskii (Fig. 2). Frozen diets based on A. siro (frozen As) and L. destructor (frozen $\mathrm{Ld}$ ) did not support the A. swirskii population, but the diet based on larvae of T. entomophagous (frozen Te) was as effective in supporting $A$. swirskii as the diet based on living mites of $A$. siro (As) and slightly less effective than the diet based on cattail, pollen (Fig. 2). Moreover, when supplied with olive pollen, predator density was significantly lower than when supplied with cattail pollen (Fig. 2).

Oviposition of $F$. occidentalis on astigmatid mite diets

The oviposition rates of western flower thrips, $F$. occidentalis, were significantly affected by food treatment $\left(\mathrm{F}_{4,84}=98.06, \mathrm{p}<0.001\right.$, Fig. 3). Oviposition rates were higher in the cattail and olive pollen treatments than in the treatments providing living and frozen stages of $T$. entomophagus, which were not significantly different from the treatment without food (Fig. 3).

\section{Discussion}

This study shows that providing prey mites in crops has substantial potential for increasing predatory mite densities. All six tested prey mite species were suitable food sources for reproduction of A. swirskii in small arenas. Three selected species, T. entomophagous, A. siro and L. destructor, were also successful in increasing densities of predatory mites in the greenhouse. The most successful prey mite in the greenhouse was T. entomophagous. When feeding on T. entomophagous diets, predatory mites reached even higher densities than when fed on cattail pollen, which is a supplemental food source that is commonly used 
Fig. 1 Daily oviposition rates of the predatory mite Amblyseius swirskii on different factitious foods based on six species of astigmatid mites [Thyreophagus entomophagus (a), Acarus siro (b), Lepidoglyphus destructor (c), Aleuroglyphus ovatus (d), Suidasia nesbitti (e) and Carpoglyphus lactis (f)], in comparison with cattail pollen (Typha angustifolia). All prey mite species were reared on dog food (high protein) or bran (high carbohydrate) as food substrates. Data presented are mean numbers of eggs $( \pm \mathrm{SE})$ per female per day based on oviposition on day 2 and 3 , since the predators were allowed to feed on the food treatments. Different letters above bars represent significant differences amongst treatments (pairwise $t$ tests after a Poisson regression with overdispersion: $\mathrm{p}<0.05$ ) (a)

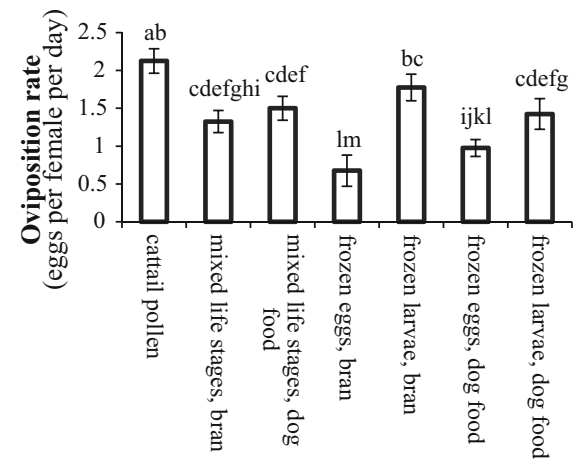

Food treatments

(c)

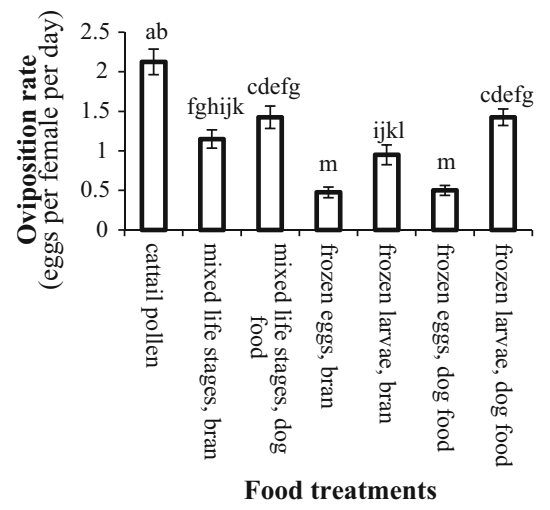

(e)

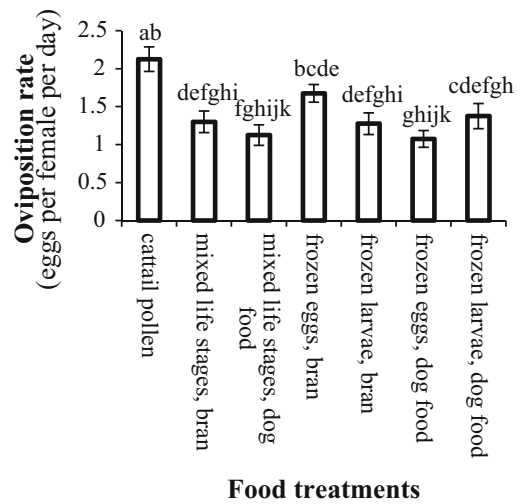

(b)

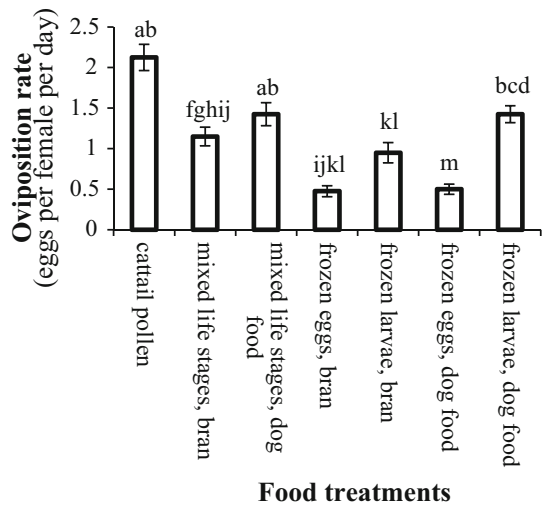

(d)

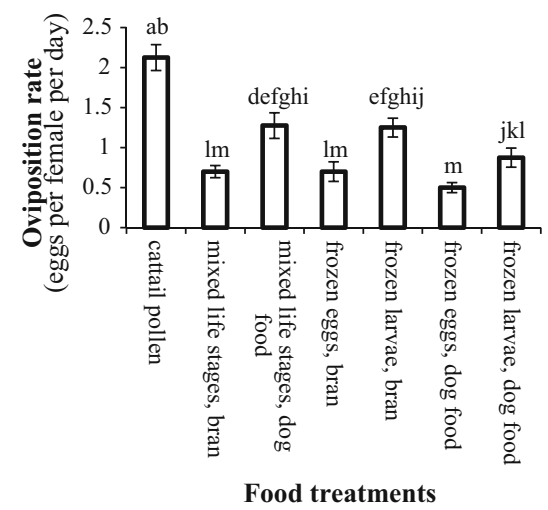

(f)

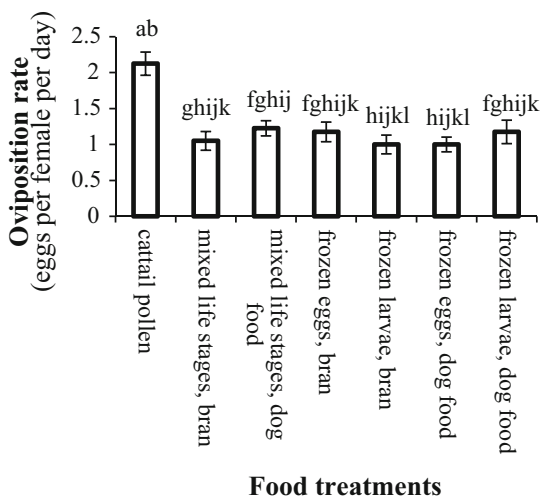

in greenhouse crops (Pijnakker et al. 2016). Lepidoglyphus destructor was the next best supplementary diet, increasing predatory mite densities to similar levels as the treatment with cattail pollen. Predatory mites performed less well on a diet of A. siro in the greenhouse trial compared with the other two prey mite species. Based on the laboratory oviposition experiment, we would have expected a different outcome. In this experiment we found the highest $A$. swirskii oviposition rates in the $A$. siro treatments. Maybe the longer developmental time of juvenile predatory mites on L. destructor and A. siro compared with $T$. entomophagous (tested on frozen stages) could explain this difference between laboratory oviposition and greenhouse results. However, other aspects of the greenhouse trial might have contributed, such as the 
Table 2 Survival and mean developmental time (days \pm SE) of immature stages of the predatory mite Amblyseius swirskii fed on different food treatments

\begin{tabular}{llllrr}
\hline Food treatments & Larva & Protonymph & Deutonymph & Total & Survival (\%) \\
\hline Cattail pollen & $1.0 \pm 0.0 \mathrm{a}$ & $1.9 \pm 0.1 \mathrm{c}$ & $1.4 \pm 0.1 \mathrm{~b}$ & $4.3 \pm 0.2 \mathrm{c}$ & $100.0 \pm 0.0 \mathrm{a}$ \\
Olive pollen & $1.0 \pm 0.0 \mathrm{a}$ & $1.1 \pm 0.1 \mathrm{~d}$ & $1.6 \pm 0.2 \mathrm{~b}$ & $3.8 \pm 0.2 \mathrm{~d}$ & $75.0 \pm 0.2 \mathrm{~b}$ \\
Frozen larvae of Acarus siro & $1.0 \pm 0.0 \mathrm{a}$ & $2.6 \pm 0.2 \mathrm{ab}$ & $1.7 \pm 0.1 \mathrm{~b}$ & $5.4 \pm 0.2 \mathrm{~b}$ & $100.0 \pm 0.0 \mathrm{a}$ \\
Frozen larvae of Lepidoglyphus destructor & $1.0 \pm 0.0 \mathrm{a}$ & $2.7 \pm 0.2 \mathrm{a}$ & $2.3 \pm 0.1 \mathrm{a}$ & $6.0 \pm 0.2 \mathrm{a}$ & $100.0 \pm 0.0 \mathrm{a}$ \\
Frozen larvae of Thyreophagus entomophagus & $1.0 \pm 0.0 \mathrm{a}$ & $2.2 \pm 0.2 \mathrm{bc}$ & $1.7 \pm 0.2 \mathrm{~b}$ & $5.0 \pm 0.2 \mathrm{~b}$ & $100 \pm 0.0 \mathrm{a}$ \\
\hline
\end{tabular}

All species of the astigmatid prey mites were reared on dog food. Different letters within the same column show significant differences amongst treatments (LSD test: $\mathrm{p}<0.05$ )

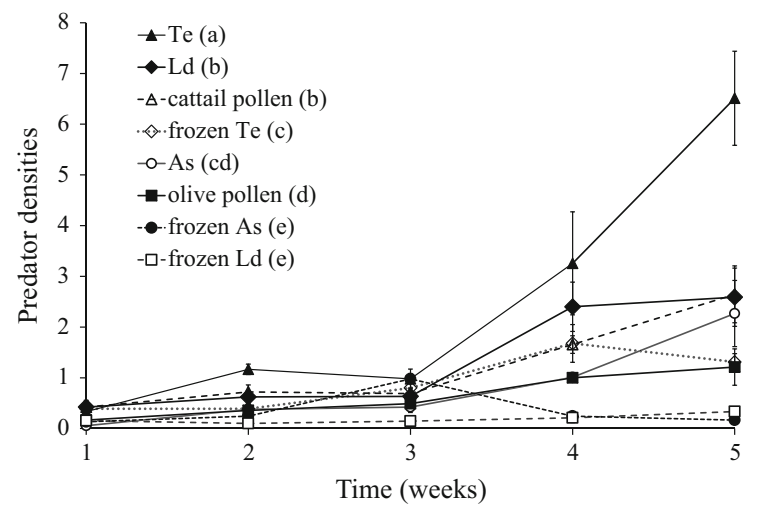

Fig. 2 Population dynamics of the predatory mite Amblyseius swirskii on chrysanthemum plants when fed on one of eight food treatments: cattail pollen (Typha angustifolia); olive pollen (Olea europaea); mixed living stages of Acarus siro (As), Lepidoglyphus destructor (Ld) and Thyreophagus entomophagus (Te); frozen larvae of A. siro (frozen As), L. destructor (frozen Ld) and T. entomophagus (frozen Te). All prey mite species were reared on dog food. Data presented are the mean $( \pm$ SE) densities of all stages of predatory mites per 18 leaves. Different letters represent significant differences amongst treatments over time (pairwise $t$ tests after a Poisson regression with overdispersion: $\mathrm{p}<0.05$ )

behaviour and survival of the living prey mites on plants. For example, L. destructor is known to run much faster than the other prey mite species evaluated, which might have affected the encounter rates with predatory mites on plants (based on personal observations). Based on the oviposition rates observed in the laboratory, we would also have expected a stronger population growth of A. swirskii on plants provided with cattail pollen than on plants with prey mites. This difference between the laboratory and greenhouse trial might be explained by the different background of the predatory mites we used. The predatory mites used in

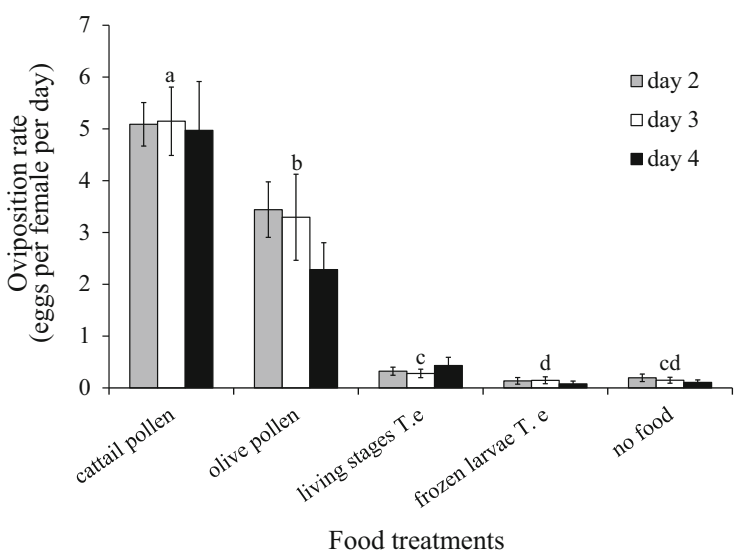

Fig. 3 Mean ( \pm SE) number of eggs per female western flower thrips, Frankliniella occidentalis per day, when feeding on one of four food treatments over three consecutive days. The food treatments were: cattail pollen (Typha angustifolia), olive pollen (Olea europaea), mixed living stages of Thyreophagus entomophagus reared on $\operatorname{dog}$ food (living T. e), or frozen larvae of $T$. entomophagus reared on dog food (frozen T. e). Different letters above bars represent significant differences amongst treatments (pairwise $t$ tests after a Poisson regression with overdispersion: $\mathrm{p}<0.05$ ), based on the average number of eggs per female produced in three days

the laboratory experiment came from cultures reared on pollen, but the predatory mites used in the greenhouse trial came from a commercial product reared on bran and prey mites. A recent study by Nemati and Riahi (2020) showed that the performance of $A$. swirskii increased after multiple generations on pollen. Thus, the predatory mites used in the laboratory experiment might have been better adapted to pollen feeding than the predatory mites used in the greenhouse trial. Another possible reason might be that pollen quality decreased faster in the greenhouse than in the laboratory. 
Although prey mites have been used for decades in mass rearing systems (Ramakers and van Lieburg 1982), little was known about their potential when applied on crops as supplemental food for predators. They have been introduced in crops, but always incidentally alongside predatory mite release, either in the carrier material applied directly to the crop or in slow-release rearing sachets (Calvo et al. 2015). Moreover, these combined releases of predatory and prey mites were mainly done with prey mite species that were optimal for mass rearing, although less suitable prey mite species have been included in slowrelease sachets to extend the release time (Bolckmans et al. 2013). Our results indicate that a wider range of prey mite species are suitable as a supplementary food source in crops than are suitable for mass rearing (predominantly the prey mite C. lactis; Calvo et al. 2015). Also the prey mite T. putrescentiae is suitable for supporting populations of $A$. swirskii, as shown in our previous study (Pirayeshfar et al. 2020), but can also cause feeding damage in young plants (Hiroshi 1991). So this limitation makes it less suitable for releasing on crops. The differences between the suitability of prey mites for mass rearing systems compared with crop application may relate to the strong effects of accumulating defensive oils that occur at high prey mite densities (Midthassel et al. 2016) in closed mass rearing systems, but are not apparent in small arenas in the laboratory or on plants where these volatiles are more diffused.

Reproduction of predatory mites was slightly better on the mites fed with dog food (protein-rich and fatrich diet) than on mites fed with bran (carbohydraterich diet) confirming our previous finding with $T$. putrescentiae (Pirayeshfar et al. 2020). This indicates that a highly nutritious prey mite diet increases the nutritional value for predatory mites. Since recent studies proved that generalist predatory mites actively balance their diet by feeding on different prey sources (Marques et al. 2015), providing high quality supplemental prey will be particularly important when other pests/prey are scarce but less important when other pests or prey are more abundant.

Frozen prey mite diets were evaluated as a possible alternative to the application of living prey mites into greenhouse crops. Frequent releases of high densities of living prey mites into crops may cause some risks for human health, since some studies indicate that astigmatid mites are able to survive in human body parts and cause acariasis ( $\mathrm{Li}$ et al. 2003). This risk would be absent when applying dead mites into crops. Our previous study with $T$. putrescentiae showed that frozen larvae were a very suitable food source for $A$. swirskii in the laboratory, but it did not increase predator populations when added to plants (Pirayeshfar et al. 2020). In the present study we found similar effects for the prey mite species $A$. siro and $L$. destructor. Frozen diets based on larvae of these species showed good results in the laboratory but not on plants in the greenhouse. However, the results with frozen larvae of $T$. entomophagous were much better in the greenhouse achieving similar effects to cattail pollen and performing better than olive pollen. The laboratory experiment also showed faster juvenile development of A. swirskii on the frozen T. entomophagous diet compared with the frozen diets of $L$. destructor and A. siro. For this reason, it might be interesting to develop a supplemental food product based on frozen larvae of T. entomophagous, although provided living T. entomophagous clearly resulted in higher predatory mite densities.

A huge benefit of using prey mites as a food source for predatory mites compared with pollen or other supplemental food sources is the unsuitability of prey mites as a food source for thrips. Our laboratory experiment showed that neither living nor dead (frozen) T. entomophagous mites increased thrips reproduction compared with the absence of food entirely. As a result of the strong numerical response of predatory mites, pollen is not a risk for thrips, in most cases. However, when thrips densities are high and predator densities are low, supplemental pollen can lead to an increase in thrips numbers (van Rijn et al. 2002; Leman and Messelink 2015; Vangansbeke et al. 2016). While olive pollen was less suitable for thrips reproduction than cattail pollen, it was also less suitable for predatory mite development in the greenhouse trial, reducing its potential as a supplemental food.

A second benefit of using prey mites as supplementary food sources is the low cost of mass production. More biocontrol companies are selling prey mite products to support predatory mite populations in greenhouse crops, as a part of a 'standing army’ strategy (Messelink et al. 2014). Applying prey mites may also have other unexpected positive effects for biological control by supporting a number of other natural enemy species. Many other predators are able 
to prey and reproduce on astigmatid mites including: soil-dwelling predatory mites (Grosman et al. 2011; Munoz-Cardenas et al. 2017), anthocorid predatory bugs (Bonte et al. 2017; Bernardo et al. 2017), spiders and rove beetles (our personal observations). Overall, we believe that providing prey mites in crops is a very interesting approach for increasing predator numbers and enhancing biological control. Specifically, for $A$. swirskii we showed that the prey mite $T$. entomophagous is the most promising candidate when applied either as living mites or as frozen larvae.

Acknowledgements We thank Dr. J. Hubert of the Crop Research Institute in Czech Republic for sending the mite $A$. ovatus, Koppert Biological systems for providing the mites $C$. lactis, L. destructor, S. nesbitti and Bioline Agrosciences for providing $T$. entomophagus. We thank Ada Leman for her stimulating discussions and help in the greenhouse trial. Urmia University supported the research of the first author for her $\mathrm{PhD}$ thesis. Moreover, she received a scholarship from the Ministry of Science, Research and Technology of Iran to visit Wageningen University \& Research in the Netherlands. The greenhouse trial was financially supported by the Dutch Topsector Horticulture \& Starting Materials (Project KV 1605 081).

\section{Declaration}

Conflict of interest The authors declare that they have no conflict of interest.

Ethical approval The authors would state that they only worked with small arthropods (insects and mites) and the international guiding principles are not applicable for these organisms.

Open Access This article is licensed under a Creative Commons Attribution 4.0 International License, which permits use, sharing, adaptation, distribution and reproduction in any medium or format, as long as you give appropriate credit to the original author(s) and the source, provide a link to the Creative Commons licence, and indicate if changes were made. The images or other third party material in this article are included in the article's Creative Commons licence, unless indicated otherwise in a credit line to the material. If material is not included in the article's Creative Commons licence and your intended use is not permitted by statutory regulation or exceeds the permitted use, you will need to obtain permission directly from the copyright holder. To view a copy of this licence, visit http://creativecommons.org/licenses/by/4.0/.

\section{References}

Arthurs S, McKenzie CL, Chen JJ, Dogramaci M, Brennan M, Houben K, Osborne L (2009) Evaluation of Neoseiulus cucumeris and Amblyseius swirskii (Acari: Phytoseiidae) as biological control agents of chilli thrips, Scirtothrips dorsalis (Thysanoptera: Thripidae) on pepper. Biol Control 49:91-96

Barbosa MFC, de Moraes GJ (2015) Evaluation of astigmatid mites as factitious food for rearing four predaceous phytoseiid mites (Acari: Astigmatina, Phytoseiidae). Biol Control 91:22-26

Bernardo AMG, de Oliveira CM, Oliveira RA, Vacacela HE, Venzon M, Pallini A, Janssen A (2017) Performance of Orius insidiosus on alternative foods. J Appl Entomol 141:702-707

Bolckmans KJF, van Houten YM (2006) Mite composition, use thereof, method for rearing the phytoseiid predatory mite Amblyseius swirskii, rearing system for rearing said phytoseiid mite and methods for biological pest control on a crop. WO Patent WO/2006/057,552

Bolckmans KJF, van Houten YM, van Baal AE, Stam AT (2013) Phytoseiid predatory mite releasing system and method for production. World Patent WO/2013/043,050. Koppert B.V.

Bonte M, van de Walle A, Conlong D, De Clercq P (2017) Eggs of Ephestia kuehniella and Ceratitis capitata, and motile stages of the astigmatid mites Tyrophagus putrescentiae and Carpoglyphus lactis as factitious foods for Orius spp. Insect Sci 24:613-622

Buitenhuis R, Murphy G, Shipp L, Scott-Dupree C (2015) Amblyseius swirskii in greenhouse production systems: a floricultural perspective. Exp Appl Acarol 65:451-464

Calvo FJ, Knapp M, van Houten YM, Hoogerbrugge H, Belda JE (2015) Amblyseius swirskii: what made this predatory mite such a successful biocontrol agent? Exp Appl Acarol 65:419-433

Erban T, Rybanska D, Hubert J (2015) Population growth of the generalist mite Tyrophagus putrescentiae (Acari: Acaridida) following adaptation to high- or low-fat and high- or low-protein diets and the effect of dietary switch. Environ Entomol 44:1599-1604

Faraji F, Janssen A, Sabelis MW (2002) Oviposition patterns in a predatory mite reduce the risk of egg predation caused by prey. Ecol Entomol 27:660-664

Gerson U, Weintraub PG (2007) Mites for the control of pests in protected cultivation. Pest Manag Sci 63:658-676

Grosman A, Messelink G, Groot Ed (2011) Combined use of a mulch layer and the soil-dwelling predatory mite Macrocheles robustulus (Berlese) enhance the biological control of sciarids in potted plants. IOBC/WPRS Bull 68:51-54

Hiroshi N (1991) Studies on acarid mites (Acari, Astigmata) damaging vegetable plants. II: damage to vegetable seedlings. Jpn J Appl Entomol Zool 35:303-309

Hoogerbrugge H, Yv H, Ev B, Bolckmans K (2008) Alternative food sources to enable establishment of Amblyseius swirskii (Athias-Henriot) on chrysanthemum without pest presence. IOBC/WPRS Bull 32:79-82

Huang H, Xu XN, Lv JL, Li GT, Wang ED, Gao YL (2013) Impact of proteins and saccharides on mass production of Tyrophagus putrescentiae (Acari: Acaridae) and its predator Neoseiulus barkeri (Acari: Phytoseiidae). Biocontrol Sci Technol 23:1231-1244

Hubert J, Stejskal V, Athanassiou CG, Throne JE (2018) Health hazards associated with arthropod infestation of stored products. Annu Rev Entomol 63:553-573 
Janssen A, Sabelis MW (1992) Phytoseiid life-histories, local predator-prey dynamics, and strategies for control of tetranychid mites. Exp Appl Acarol 14:233-250

Janssen A, Sabelis MW (2015) Alternative food and biological control by generalist predatory mites: the case of Amblyseius swirskii. Exp Appl Acarol 65:413-418

Johansson E, Johansson SGO, Vanhagehamsten M (1994) Allergenic characterization of Acarus siro and Tyrophagus putrescentiae and their cross-reactivity with Lepidoglyphus destructor and Dermatophagoides pteronyssinus. Clin Exp Allergy 24:743-751

Kenward MG, Roger JH (1997) Small sample inference for fixed effects from restricted maximum likelihood. Biometrics 53:983-997

Kumar V, Wekesa VW, Avery PB, Powell CA, McKenzie CL, Osborne LS (2014) Effect of pollens of various ornamental pepper cultivars on the development and reproduction of Amblyseius swirskii (Acari: Phytoseiidae). Fla Entomol 97:367-373

Leman A, Messelink GJ (2015) Supplemental food that supports both predator and pest: a risk for biological control? Exp Appl Acarol 65:511-524

Li CP, Cui YB, Wang J, Yang QG, Tian Y (2003) Acaroid mite, intestinal and urinary acariasis. World $\mathrm{J}$ Gastroenterol 9:874-877

Marques RV, Sarmento RA, Lemos F, Pedro-Neto M, Sabelis MW, Venzon M, Pallini A, Janssen A (2015) Active prey mixing as an explanation for polyphagy in predatory arthropods: synergistic dietary effects on egg production despite a behavioural cost. Funct Ecol 29:1317-1324

McCullagh P, Nelder JA (1983) Generalized linear models, 2nd edn. Chapman and Hall, London

McMurtry JA, De Moraes GJ, Sourassou NF (2013) Revision of the lifestyles of phytoseiid mites (Acari: Phytoseiidae) and implications for biological control strategies. Syst Appl Acarol 18:297-320

Messelink GJ, van Steenpaal SEF, Ramakers PMJ (2006) Evaluation of phytoseiid predators for control of western flower thrips on greenhouse cucumber. Biocontrol 51:753-768

Messelink GJ, van Maanen R, van Steenpaal SEF, Janssen A (2008) Biological control of thrips and whiteflies by a shared predator: two pests are better than one. Biol Control 44:372-379

Messelink GJ, Ramakers PMJ, Cortez JA, Janssen A (2009) How to enhance pest control by generalist predatory mites in greenhouse crops. In: Mason PG, Gillespie DR, Vincent $\mathrm{C}$ (eds) 3rd international symposium on biological control of arthropods, Christchurch, New Zealand. pp 309-318

Messelink GJ, van Maanen R, van Holstein-Saj R, Sabelis MW, Janssen A (2010) Pest species diversity enhances control of spider mites and whiteflies by a generalist phytoseiid predator. Biocontrol 55:387-398

Messelink GJ, Bennison J, Alomar O, Ingegno BL, Tavella L, Shipp L, Palevsky E, Wäckers FL (2014) Approaches to conserving natural enemy populations in greenhouse crops: current methods and future prospects. Biocontrol 59:377-393

Midthassel A, Leather SR, Baxter IH (2013) Life table parameters and capture success ratio studies of Typhlodromips swirskii (Acari: Phytoseiidae) to the factitious prey
Suidasia medanensis (Acari: Suidasidae). Exp Appl Acarol 61:69-78

Midthassel A, Leather S, Wright DJ, Baxter IH, Farman DI, Cork A (2016) An astigmatid defence volatile against a phytoseiid mite. Entomol Exp Appl 158:97-107

Munoz-Cardenas K, Ersin F, Pijnakker J, van Houten Y, Hoogerbrugge H, Leman A, Pappas ML, Duarte MVA, Messelink GJ, Sabelis MW, Janssen A (2017) Supplying high-quality alternative prey in the litter increases control of an above-ground plant pest by a generalist predator. Biol Control 105:19-26

Nemati A, Riahi E (2020) Does feeding on pollen grains affect the performance of Amblyseius swirskii (Acari: Phytoseiidae) during subsequent generations? Bull Entomol Res 110:449-456

Nemati A, Riahi E, Moghadam AK, Gwiazdowicz DJ, Bahari MR, Amini P (2019) Comparison of different pollen grains and a factitious prey as food sources for Amblyseius swirskii (Acari: Phytoseiidae). Syst Appl Acarol 24:2427-2438

Nguyen DT, Vangansbeke D, Lu X, De Clercq P (2013) Development and reproduction of the predatory mite Amblyseius swirskii on artificial diets. Biocontrol 58:369-377

Nomikou M, Janssen A, Schraag R, Sabelis MW (2002) Phytoseiid predators suppress populations of Bemisia tabaci on cucumber plants with alternative food. Exp Appl Acarol 27:57-68

Nomikou M, Sabelis MW, Janssen A (2010) Pollen subsidies promote whitefly control through the numerical response of predatory mites. Biocontrol 55:253-260

Pijnakker J, Arijs Y, Souza Ad, Cellier M, Wackers F (2016) The use of Typha angustifolia (cattail) pollen to establish the predatory mites Amblyseius swirskii, Iphiseius degenerans, Euseius ovalis and Euseius gallicus in glasshouse crops. IOBC/WPRS Bull 120:47-54

Pirayeshfar F, Safavi SA, Sarraf Moayeri HR, Messelink GJ (2020) The potential of highly nutritious frozen stages of Tyrophagus putrescentiae as a supplemental food source for the predatory mite Amblyseius swirskii. Biocontrol Sci Technol 30:403-417

Ramakers PMJ, van Lieburg MJ (1982) Start of commercial production and introduction of Amblyseius mckenziei Sch. \& Pr. (Acarina: Phytoseiidae) for the control of Thrips tabaci Lind. (Thysanoptera: Thripidae) in glasshouses. Med Fac Landbouw Rijksuniv Gent 47:541-545

Riahi E, Fathipour Y, Talebi AA, Mehrabadi M (2017) Natural diets versus factitious prey: comparative effects on development, fecundity and life table of Amblyseius swirskii (Acari: Phytoseiidae). Syst Appl Acarol 22:711-723

Sabelis MW (1990) How to analyse prey preference when prey density varies? a new method to discriminate between effects of gut fullness and prey type composition. Oecologia 82:289-298

Schliesske J (1981) Ueber die technik der massenanzucht von raubmilben (Acari: Phytoseiidae) unter kontrollierten bedingungen. Med Fac Landbouw Rijksuniv Gent 46:511-517

Simoni S, Nannelli R, Goggioli D, Guidi S, Castagnoli M (2006) Biological and demographic parameters of Neoseiulus californicus (McGregor) (Acari Phytoseiidae) reared on two astigmatid mites. Redia 89:59-63 
Teulon DAJ, Penman DR (1991) Effects of temperature and diet on oviposition rate and development time of the New Zealand flower thrips, Thrips obscuratus. Entomol Exp Appl 60:143-155

van Rijn PCJ, Tanigoshi LK (1999) The contribution of extrafloral nectar to survival and reproduction of the predatory mite Iphiseius degenerans on Ricinus communis. Exp Appl Acarol 23:281-296

van Lenteren JC, Bolckmans K, Kohl J, Ravensberg WJ, Urbaneja A (2018) Biological control using invertebrates and microorganisms: plenty of new opportunities. Biocontrol 63:39-59

van Maanen R, Vila E, Sabelis MW, Janssen A (2010) Biological control of broad mites (Polyphagotarsonemus latus) with the generalist predator Amblyseius swirskii. Exp Appl Acarol 52:29-34

van Rijn PCJ, van Houten YM, Sabelis MW (2002) How plants benefit from providing food to predators even when it is also edible to herbivores. Ecology 83:2664-2679

Vangansbeke D, Nguyen DT, Audenaert J, Verhoeven R, Gobin B, Tirry L, De Clercq P (2016) Supplemental food for Amblyseius swirskii in the control of thrips: feeding friend or foe? Pest Manag Sci 72:466-473

Winston PW, Bates DH (1960) Saturated solutions for the control of humidity in biological research. Ecology 41:232-237
Fatemeh Pirayeshfar is $\mathrm{PhD}$ of Agricultural Entomology (ecology and biological control) from Urmia University, Iran. Her research interests focuses on the development of new sources of alternative foods for biological control agents, especially predators.

Seyed Ali Safavi was born in Tabriz, Iran. He received his $\mathrm{PhD}$ degree in Agricultural Entomology from University of Tehran, Karaj, Iran in 2007. He is currently the full professor of Urmia University, Urmia, Iran. His research work has been mainly concerned with the biological control of insect pests including predators, parasitoids and entomopathogens with special emphasis on fungal biocontrol agents.

Hamid Reza Sarraf Moayeri recieved his $\mathrm{PhD}$ degree from University of Tehran, Karaj, Iran in 2007. His research interests focus on insect biocontrol and ecology. He currently serves as an associate professor at Department of plant protection, University of Zanja, Iran.

Gerben Messelink is an applied entomologist at Wageningen University \& Research, BU Greenhouse Horticulture in The Netherlands. His work focuses on the development of biological control systems for pests in greenhouse crops. 